\title{
Corporate Governance Ratings and Market-based Financial Performance: Evidence from Turkey
}

\author{
Emre Ergin \\ Correspondence: Emre Ergin, Assistant Professor, Accounting and Tax Program, Izmit Vocational School, \\ Arslanbey Campus, Kocaeli University, Kocaeli, Turkey. Tel: 90-262-351-3287(126). E-mail: \\ emre.ergin@kocaeli.edu.tr
}

Received: July 2, 2012

Accepted: July 25, 2012

Online Published: July 27, 2012

doi:10.5539/ijef.v4n9p61

URL: http://dx.doi.org/10.5539/ijef.v4n9p61

\begin{abstract}
Corporate governance ranking is a recent issue for Turkish firms. Although the new regulations in Turkey encourage the firms to get corporate ratings, firms are not obliged to get them. It is those firms which trade their stocks in the Istanbul Stock Exchange (ISE) that are interested in governance ratings, while corporate governance rating is a luxury for firms that do not trade their stocks publicly. The objective of this paper is to investigate whether or not investors take the corporate governance rankings into account in their evaluation of stock price. Since the first rating was in 2006, all the rated firms quoted to ISE were examined for the years 2006 to 2010 using a price model. Further analysis is carried out in order to assess the total impact of corporate governance on stock price by eliminating any correlation between the independent accounting variables and corporate governance scores. The results suggest that the corporate governance rankings are positively and significantly associated not only with the financial performance but also with the accounting performance. The sub-components of corporate governance that have a positive association to the financial performance are stakeholders, and public disclosure and transparency.
\end{abstract}

Keywords: corporate governance, rating, financial performance, investors, Turkey

\section{Introduction}

The need for corporate governance is undeniable. However, whether or not the corporate governance improves firm performance is another question of which the answer is not clear. Agency problems and the opportunistic behavior of managers distort the effectiveness of corporate governance. The main point of the emergence of the agency problem is the owners who stay distant from control; hence, the decisions of the management diverge from those of the owners. The need for corporate governance to limit conflicts of interests between shareholders and managers has been known long before. Berle and Means (1932) stated that managers must be controlled in order to avoid losses. Smith (1937) argued that negligence and profusion prevail while managing other people's money rather than their own. Financial scandals like the ones which occurred at Enron, World.com, Parmalat, Nortel, and Imar Bank and the enormous costs they brought about have reinforced this argument. Such scandals cause financial markets to drop sharply, investors to lose their savings, people to lose their jobs, and tax collections to reduce.

Financial scandals in several countries have served as justification for new legislation to regulate corporate governance practices. For instance, the USA passed the Sarbanes-Oxley Act in 2002. In July 2011, the Dodd-Frank Wall Street Reform and Consumer Protection Act passed in order to prevent another financial crisis. In 2005 the UK updated Turnbull Guidance on Internal Control which is planned to be reviewed during 2012. Germany passed the law on the corporate governance principles so these principles have become a legal obligation. Many other countries publish or re-examine their legislation within the framework of corporate governance. Turkey has also been affected by the domestic and global financial crises. The most severe ones occurred last two decades, specifically in 1994, 1998, 2001, and 2008. As a result, in July 2003 Turkey published corporate governance principles adopted from the Organization for Economic Co-operation and Development (OECD) principles of corporate governance, and in February 2005 revised them.

Corporate governance is a set of mechanism which aims to reduce the principal-agent problem, hence to increase shareholders' welfare. However, the scope of corporate governance is beyond shareholders as the fund suppliers and all other stakeholders profit from management who will increase firm performance. Performance measures 
are divided into two primary categories: accounting-based (such as operating income, earnings before interest and tax, and profit before or after tax) and market-based (such as market value, stock returns, and dividend yield) Investors follow performance measures according to their scope of interests. Corporate governance ratings may be a valuable measure to assess firms' financial performance as they assess firms from a different perspective. A study analyzing crisis period suggests that firm value is a function of firm-level differences in corporate governance measures (Baek, Kang, \& Park, 2004). Investors are willing to pay the fees charged by rating intermediaries as they perceive that the governance scores offer valuable information for investment decisions (Gupta, Kennedy, \& Weaver, 2009).

This paper adds new empirical results to the relationships between firm value and corporate governance practices. The model separately tests both the total composite governance score and the four sub-indices of the composite corporate governance scores. There are two main points of interest in the analysis. Firstly, the change of the adjusted $\mathrm{R}^{2}$ is examined for each of the model constructed. Secondly, positive and significant relations between the governance rating and the market value of the firms point to the positive association between governance practices and financial performance of firms. While Section 2 reviews the literature, Section 3 shortly explains the corporate governance in Turkey. Section 4 presents the research and the results, and Section 5 gives the conclusion of this study.

\section{Literature}

\subsection{Corporate Governance}

Shleifer and Vishny (1997) give a broad definition of corporate governance: it concerns the ways in which suppliers of funds and the corporation themselves ensure returns on investment. A good corporate governance system should provide a kind of legal protection (Shleifer \& Vishny, 1997) to investors in order to minimize the agency costs. In a similar approach, Picou and Rubach (2006) define corporate governance as the entire rules, methods and incentives that will harmonize the accord between agent (executive board and management) and shareholders (those who supply capital). Kyereboah-Coleman and Biekpe (2006) interpret it as a mechanism that shapes legal protection (firm laws, stock exchange quotation conditions, and accounting standards). In sum, there is not a common understanding either on the meaning of corporate governance or on the elements needed to obtain a good governance framework (Gupta, Kennedy, \& Weaver, 2006).

According to the OECD, corporate governance involves relations among the management, board of directors, shareholders, and stakeholders of a firm. Corporate governance is a structure that displays a firm's objectives, how to reach these objectives, and how to follow the firm's performance. Good corporate governance helps management take proper actions so as to reach the firm's objectives and shareholders' interests. The existence of an effective corporate governance system, both in firm dimension and macroeconomic dimension, gives to related parties the confidence that the market economy will function in a healthier way (OECD, 2004).

Besides these current definitions on corporate governance, there is no real consensus on the components of good corporate governance among academicians and practitioners. Most of the research done until today examines a specific component: board of directors component, shareholders component, salary topics component, the rights of the stakeholders component, etc. The singular approach of these studies could not have an integrated model for good corporate governance (Berthelot, Morris, \& Morill, 2010). This study examines all of the four main components of corporate governance in the same model.

Certain institutions perform corporate governance ratings even though there is not a common framework for good corporate governance. For instance, Standard and Poor's has developed Standard and Poor's Corporate Governance Scores. Ownership structure, effects of external stakeholders, investors' rights and relations, transparency and disclosures, structure of board of directors and components (like process) are included in their rating framework. The same institution has developed the GAMMA Score (Standard and Poor's, GAMMA) for the firms in the emerging markets. The scores published by Governance Metrics International include the accountability of the board of directors, the disclosure of financial statements and internal controls, the rights of the shareholders, salary package, market and corporate behavior components. Institutional Shareholder Service evaluates firms according to the board of directors, audits, the contracts and regulations of firms, the regulations against a takeover, the salary packages of board of directors who have an executive responsibility, top management, ownership and data on the educational background of the managers.

\subsection{Corporate Governance and Firm Performance}

Although it is assumed that the minority shareholders are more subject to agency problems than majority shareholders are, the primary aim of the corporate governance is the protection of shareholders in general. 
Therefore, better governance would mean that an investor's fund would be better used to give excess returns to shareholders. The returns may be in the form of dividends and/or increased market value. In either way, it means that governance achieves this excess by operating performance. Those firms which have above average operating profit ratios have higher positive cash flows and profits to distribute. This situation will also attract potential investors who will increase the share price, hence market value.

However, empirical studies may not always establish this positive link between corporate governance and firm performance. The main reason of this inconsistency is that generally researchers investigate the relation of corporate governance by focusing on different factors and isolating the other factors in order to determine which factor effectively controls the conflict of interest between shareholders and management. One of the earliest researches on the relationship between the corporate governance and firm performance was done by Black (2001) who found a positive correlation between them. One shortcoming of his study was that the sample he used consisted of 20 firms only. Gombers, Ishii, and Metrick (2003) constructed a governance index and found that stronger shareholders rights had higher profits and higher firm value. Bebchuk, Cohen, and Ferrell (2009) identified the six provisions (namely, staggered boards, limits to shareholder bylaw amendments, poison pills, golden parachutes, and supermajority of requirements for mergers and charter amendments) out of 24 which reduce the firm value when the level of these provisions increases. They contributed to the understanding of the positive link between corporate governance and firm performance by showing which provision affects the firm value. Contrary to Gombers et al. (2003) and Bebchuk et al. (2009) who focused on external governance, Brown and Caylor (2006) created Gov-Index using both internal and external governance that showed the positive relation to firm value. Larcker, Richardson, and Tuna (2007) used 39 structural measures of corporate governance and concluded that their governance indices are related to future operating performance and excess stock returns. In the literature, some studies argue against a positive relationship between governance and performance. For instance, the researches of Yen (2005), Core, Guay, and Rusticus (2006), Ferreira and Laux (2007), and Chidambaran, Palia, and Zheng (2008) fall into this category.

\section{Corporate Governance in Turkey}

The evolvement of capital markets and the recent crises that led to the bankruptcy of important firms obliged the authorities in Turkey to take measures on corporate governance. The first shock for Turkey was the 1997-1998 East-Asian economic crisis. To deal with high inflation and unsustainable growth, the country implemented the crawling peg system, an IMF supported exchange rate based stabilization program. However, this global shock was followed by the financial crisis in Turkey in 2001 when many institutions went bankrupt. The GNP of the country was reduced by $5.7 \%$ in real terms, consumer price inflation increased to $55 \%$, the Turkish currency lost its value more than $50 \%$ against hard currencies, and the rate of unemployment exceeded $10 \%$ in 2001 . This shock was absorbed when Turkey implemented "Transition to Strong Economy" program monitored by IMF and the World Bank. Banks which went bankrupt were taken over by Savings Deposit Insurance Fund, which later liquidated or sold those banks. The costs of the close down of the banks were estimated $\$ 50$ billion. Turkish government issued bonds to make the payments of the losses. One decade after the $2001 \mathrm{crisis}$, it was declared that the inflation adjusted payments of these government bonds amounted to a loss of TL252 billion on Turkish economy. Among more than twenty banks that were bankrupt, Imar Bank scandal was one of the greatest banking corruption cases in the Turkish Republic, and the sum of the fraud amounted to $\$ 7,2$ billion (even greater than Société General Bank scandal in which the bank lost $€ 4,9$ billion). This incidence showed the degree to which the corporate governance was needed in Turkey. New regulations were established in Turkey. Capital Markets Board of Turkey (SPK, 2005) set up guidelines for corporate governance in 2003. In 2005, guidelines were revised and categorized under four captions which are shareholders, public disclosure and transparency, stakeholders and board of directors.

However, today, almost $99 \%$ of the firms in Turkey are categorized as small and medium sized firms. Thus, it is difficult to protect shareholders rights by imposing such mechanisms as disclosure standards, independent board members, and to oblige those firms to assess themselves on corporate governance ratings.

According to the Credit Rating Activities and the Principles for Rating Institutions communique issued by Capital Markets Board of Turkey on July 12, 2007, the following institutions were authorized for corporate governance rating (SPK, 2007):

1. Turkish Credit Rating Inc.

2. SAHA Corporate Governance and Credit Rating Services Inc.

3. Kobirate International Credit Rating and Corporate Governance Services Inc. 
4. JCR Eurasi Rating Inc.

5. RiskMetrics Group, Inc.

The first four rating institutions were founded in Turkey while the last one is authorized to operate in Turkey. By the scores given to the firms, these firms try to help investors better assess and manage risks related to the financial markets. They provide independent assessment, transparency, and expertise.

\section{Research Design}

\subsection{Model}

In order to investigate the relationship between the corporate governance and sub-index scores published by the agencies named above and the financial performance of the firms, the model (Berthelot et al., 2010) in equation (1) is used:

$$
P_{j t+y}=\alpha_{0}+\alpha_{1} B V E_{j t}+\alpha_{2} N I_{j t}+\alpha_{3-6} C G S+\alpha_{7-10} Y_{j t}+\varepsilon_{j t}
$$

where $P_{j t+y}$ is the share price of firm $j$ at the end of the last fiscal period, $B V E_{j t}$ is the book value of equity of firm $j$ at time t, divided by the number of shares at time $t, N I_{j t}$ is the net income of firm $j$ at time $t$, divided by the number of shares at time $t, C G S_{j t}$ is the composite corporate governance scores and sub-scores published by the authorized agencies in Turkey, $Y_{j t}\left(\mathrm{~A} 2006_{\mathrm{jt}}, \mathrm{A} 2007_{\mathrm{jt}}, \mathrm{A} 2008_{\mathrm{jt}}, \mathrm{A} 2009_{\mathrm{jt}}, \mathrm{A} 2010_{\mathrm{jt}}\right.$ ), where $\mathrm{A} 2006_{\mathrm{jt}}\left(\mathrm{A} 2007_{\mathrm{jt}}\right.$, $\mathrm{A} 2008_{\mathrm{jt}}, \mathrm{A} 2009_{\mathrm{j}}, \mathrm{A} 2010_{\mathrm{jt}}$ ) is a dummy variable representing each year covered by the observations and is equal to 1 if the year covered by the observation is $2006(2007,2008,2009,2010)$ and 0 otherwise, and $\varepsilon_{j t}$ is an error term. CGS(T) is the total composite CGS for firm $j$ at year $t$. There are four sub-indices of CGS: CGS(S) is the CGS sub-index score on shareholders for firm $j$ at year $t, \operatorname{CGS}(\mathrm{P})$ is the sub-index score on public disclosure and transparency for firm $j$ at year $t, \operatorname{CGS}(\mathrm{St})$ is the CGS sub-index score on stakeholders for firm $j$ at year $t$, CGS(D) is the CGS sub-index score on board of directors for firm $j$ at year $t$.

This model relates share price to book value of equity $\left(B V E_{j t}\right)$ and current net income $N I_{j t}$. The effects of the corporate governance scores stock price are tested by regression coefficients $\alpha_{3-6}$. These coefficients should be positive and significantly different from zero. Dummy variables are included to control for fixed year effects.

The sample used in this study is composed of all Turkish companies quoted at ISE and those which are rated by the agency mentioned in Section 3 of this study. The period starts from 2006 when the ratings first began. The data are retrieved either from the web sites of the credit rating agencies or from the web sites of the firms. Accounting and share price data are available on the www.ise.gov.tr database. There are 29 firms in total for 70 observations. One firm had its rating revised during the same year, so its former rating was not included in the analysis leaving 69 observations for the final sample.

\subsection{Results}

Table 1 presents descriptive statistics for the variables included in the analysis. The mean market capitalization was TL3,415,911,000, the mean book value was TL1,965,180,000, and the mean net income was TL312,214,000. The figures of the firms in the analysis show that these firms are important players in the market. The mean composite corporate governance score is $81.81 / 100$. The mean shareholders sub-score is $81.60 / 100$ or $20.4 / 25$, the mean public disclosure and transparency is $88.02 / 100$ or $30.81 / 35$, the mean stakeholders sub-score is $88.13 / 100$ or $13.22 / 15$, and the mean board of directors sub-score is $69.50 / 100$ or $17.38 / 25$. 
Table 1. Descriptive statistics

\begin{tabular}{lrrrrr}
\hline Variables & \multicolumn{1}{c}{ Mean } & Std.Dev. & Median & Minimum & Maximum \\
\hline MV & $3,415,911$ & $4,710,446$ & $1,721,953$ & 30,100 & $22,750,000$ \\
BVE & $1,965,180$ & $2,485,746$ & $1,253,449$ & 31,375 & $14,319,892$ \\
NI & 312,214 & 592,294 & 114,035 & $-408,064$ & $2,772,819$ \\
CGS(T) & 81.81 & 3.85 & 82.00 & 70.80 & 90.35 \\
CGS(BC) & 81.60 & 5.93 & 82.27 & 57.70 & 90.46 \\
CGS(C) & 88.02 & 5.22 & 88.31 & 73.27 & 97.27 \\
CGS(SR) & 88.13 & 7.31 & 90.51 & 66.30 & 98.21 \\
CGS(D) & 69.50 & 6.24 & 68.48 & 56.36 & 84.02 \\
\hline
\end{tabular}

Notes. $\mathrm{n}=69$. Financial data are in thousands of Turkish Lira. MV is the market value or capitalization. BVE is the book value of equity at the year ends of the financial statements. NI is the net income at the year ends of the financial statements.

Table 2 presents the Pearson correlations among test variables. The largest correlations are between the MV, BVE and NI variables. Correlations between composite governance and sub-index scores are also significant. Accounting and financial variables are correlated only with stakeholders sub-score with correlations ranging between $0.28-0.33$.

Table 2. Correlation between variables

\begin{tabular}{lccccccc}
\hline & BVE & NI & CGS(T) & CGS(BC) & CGS(C) & CGS(SR) & \multicolumn{2}{c}{ CGS(D) } \\
\hline MV & $0.77^{* *}$ & $0.87^{* *}$ & 0.15 & 0.03 & 0.14 & $0.33^{* *}$ & -0.05 \\
BVE & & $0.89^{* *}$ & 0.14 & -0.03 & 0.16 & $0.28^{* *}$ & -0.02 \\
NI & & 0.03 & -0.13 & 0.10 & $0.29^{* *}$ & -0.12 \\
CGS(T) & & & $0.72^{* *}$ & $0.78^{* *}$ & $0.41^{* *}$ & $0.58^{* *}$ \\
CGS(BC) & & & & $0.40^{* *}$ & $0.27^{*}$ & 0.17 \\
CGS(C) & & & & & 0.14 & $0.30^{* *}$ \\
CGS(SR) & & & & & & -0.10 \\
\hline
\end{tabular}

Notes. $\mathrm{n}=69{ }^{* *},{ }^{*}$ significant at the .01 and .05 percent levels (one-tailed test), respectively.

The results of the estimation of equation (1) are presented in Table 3. The adjusted $R^{2}$ for Model-1 indicates that the independent variables book value of equity (BVE) and net income (NI) explain 79.7 percent of the stock price variation. After adding the composite governance score to obtain Model-2, the coefficient has a positive value (2.13) as predicted, and significantly different from zero. The adjusted $R^{2}$ of Model-2 is 80.5 percent, hence only 0.8 percent higher than that of Model-1. Adjusted $R^{2}$ is used instead of $R^{2}$ as adjusted $R^{2}$, unlike ordinary $R^{2}$, which increases only if the new independent variable improves the model than would be expected by chance. 
Table 3. Regression results

\begin{tabular}{|c|c|c|c|c|c|c|c|c|}
\hline Variables & Predicted sign & Model-1 & Model-2 & Model-3 & Model-4 & Model-5 & Model-6 & Model-7 \\
\hline Constant & (?) & 0.41 & $-16.96^{*}$ & $-17.95^{*}$ & $6.89^{* * *}$ & -11.952 & $6.89^{* * *}$ & $-23.82^{* *}$ \\
\hline BVE & $(+)$ & $1.11^{* * * *}$ & $1.10^{* * * *}$ & $1.07^{* * *}$ & $4.14^{* * * *}$ & $4.14^{* * * *}$ & $3.80^{* * * *}$ & $3.80^{* * *}$ \\
\hline NI & $(+)$ & $3.73^{* * *}$ & $3.78^{* * *}$ & $3.70^{* * *}$ & $3.80^{* * *}$ & $3.80^{* * *}$ & $3.36^{* * *}$ & $3.36^{* * *}$ \\
\hline CGS(T) & $(+)$ & - & $2.13^{*}$ & - & - & $2.30^{* *}$ & - & - \\
\hline CGS(BC) & $(+)$ & - & - & 0.78 & - & - & - & 0.05 \\
\hline CGS(C) & $(+)$ & - & - & 0.53 & - & - & - & $2.17^{* *}$ \\
\hline CGS(SR) & $(+)$ & - & - & 0.76 & - & - & - & $3.81^{* * *}$ \\
\hline CGS(D) & $(+)$ & - & - & 0.13 & - & - & - & $-3.22^{* * *}$ \\
\hline Adjusted $R^{2}$ & & 0.797 & 0.805 & 0.798 & 0.796 & 0.805 & 0.603 & 0.798 \\
\hline$F$-statistics & & 134.865 & 94.312 & 45.810 & 133.424 & 94.312 & 52.699 & 45.810 \\
\hline
\end{tabular}

Model-3 adds all the four sub-indices to Model-1. The results of the regression analysis show that the coefficients for the four components of the composite governance index are positive, as predicted, but not significantly different from zero. All of the four sub-indices are, therefore, not related to share price.

From Table 2, it is noted that corporate governance sub-index CGS(St) shows a significant correlation with accounting variables (BVE and NI). Therefore, some of the effects of corporate governance and its sub-indices are embodied in the accounting variables which complicate the evaluation of the total influence of corporate governance on share price. In order to eliminate these multicollinearity problems, the two independent accounting variables (BVE and NI) are regressed on the composite governance scores, and the standardized residuals of these auxiliary regressions are used in place of the raw accounting variables in Model-4 and Model-5. Therefore, any correlation between the adjusted accounting variables and the corporate governance scores are eliminated. In Model-4, independent accounting variables book value of equity and net income explain 79.6 percent of the variation in stock prices which was almost the same in Model-1. This confirms that the correlation between accounting variables and the total composite governance score are not significantly correlated as shown on Table 2. Thus, adding the total composite governance score variable to the regression (Model-5) makes the adjusted $R^{2}$ unchanged from the Model-1. The coefficients of the independent variables in Model- 4 and Model-5 are positive, as predicted, and different from zero.

In Models 6 and 7, the analysis is repeated as for the Model 4 and 5. However, this time, each of the accounting variables (BVE and NI) is regressed on the four sub-index scores instead of the total composite score as done for the Models 4 and 5. Then, the residuals from these auxiliary regressions are used as independent variables instead of raw accounting variables in Models 6 and 7. Therefore, Models 6 and 7 eliminate the multicollinearity problems between accounting data and all of the sub-components of the corporate governance scores. The new model obtained as Model-6 explains 60.3 percent of the variation in stock price. This gives evidence that CGS sub-index score on stakeholders, CGS(St), is embodied in the accounting variables. In reality, 19.4 percent (79.7-60.3) of the adjusted $R^{2}$ of Model-1 is explained by the corporate governance score even though Model-1 takes only two accounting variables into consideration. Adding four sub-index scores as independent variables in Model-7 the overall explanatory power increases by 19.5 percent to reach 79.8 percent. In Model-7, the coefficients of CGS(P) and CGS(St) are positive, as predicted, and different from zero. However, CGS(S) is not different from zero, and CGS(D) coefficient is negative. The findings are consistent with those of Klein, Shapiro, and Young (2005), and Berthelot et al. (2010). According to the empirical results of this study, CGS(St), stakeholders sub-score, is the most important sub-component of the corporate governance. It can be asserted that effective communication and cooperation between the firm and its stakeholders have a positive impact on a firm's performance in the market. Investors value firms with high CGS(St) ratings. Additionally, investors take account a firm's high public disclosure and transparency ratings (CGS(P)) because of the need of shareholders and investors for regular and reliable information about the firm. Results show that corporate governance rankings are reflected in the market values.

\section{Conclusion}

The main aim of this paper was to examine whether or not investors consider the published corporate governance ranking in their evaluation of stock price. The results indicate that investors take the corporate governance 
ratings into account in their stock price evaluations. The results also point out that some components of the firms' corporate governance appear to be associated with their accounting results. It implies that the corporate governance scores capture practices that could impact the firms' accounting results, namely net income and shareholder equity. The results of the Turkish study are in parallel with the study of Berthelot et. al. (2010) who researched Canadian firms. As they also pointed out, investors are interested in good corporate governance practices which affect the market capitalization directly.

It is concluded that corporate governance ratings have an impact on investors' evaluation of stock price. However, the effects of the sub-components of the corporate governance are not the same. The study shows significant positive relationships between financial performance and two of the CGS sub-index, namely stakeholders, and public disclosure and transparency. The outcomes of this study may help trace the financial performance of the firms to different sub-components of the corporate governance rating.

\section{References}

Baek, J., Kang, J., \& Park, K. (2004). Corporate governance and firm value: Evidence form the Korean financial crisis. Journal of Financial Economics, 71(2), 265-313. http://dx.doi.org/10.1016/S0304-405X(03)00167-3

Bebchuk, L., Cohen, A., \& Ferrell, A. (2009). What matters in corporate governance? Review of Financial Studies, 22(2), 783-827. http://dx.doi.org/10.1093/rfs/hhn099

Berle, A., \& Means, G. (1932). The modern corporation and private property. Macmillan, 7th ed. 2005, New York, NY.

Berthelot, S., Morris, T., \& Morrill, C. (2010). Corporate governance rating and financial performance: A Canadian study. Corporate Governance, 10(5), 635-646.

Black, B. (2001). The corporate governance behavior and market value of Russian firms. Emerging Markets Review, 2(2), 89-108.

Brown, L. D., \& Caylor, M. L. (2006). Corporate governance and firm valuation. Journal of Accounting and Public Policy, 25(4), 409-434. http://dx.doi.org/10.1016/j.jaccpubpol1.2006.05.005

Chidambaran, N. K., Palia, D., \& Zheng, Y. (2008). Corporate governance and firm performance: Evidence from large governance changes. Retrieved from http://papers.ssrn.com/sol3/papers.cfm?abstract_id=1108497

Core, J., Guay, W. R., \& Rusticus, T. O. (2006). Does weak governance cause weak stock returns? An examination of firm operating performance and investors' expectation. Journal of Finance, 61(2), 655-687.

Ferreira, M., \& Laux, P. A. (2007). Corporate governance, idiosyncratic risk, and information flow. Journal of Finance, 62(2), 951-990.

Gombers, P., Ishii, J., \& Metrick, A. (2003). Corporate governance and equity prices. Quarterly Journal of Economics, 118(1), 107-156.

Gupta, P. P., Kennedy, D. B., \& Weaver, S. W. (2006). Corporate governance scores, Tobin's q and equity prices: Evidence from Canadian capital markets. Working paper. Retrieved from http://accounting.uwaterloo.ca/seminars/old_papers/Duane $\% 20$

Kennedy\%20-020GKW\%20Governance_Paper_January_30_2006.pdf

Gupta, P. P., Kennedy, D. B., \& Weaver, S. W. (2009). Corporate governance and firm value: Evidence from Canadian capital markets. Corporate Ownership and Control, 6(3), 293-307.

Klein, P., Shapiro, D., \& Young, J. (2005). Corporate governance, family ownership and firm value: The $\begin{array}{lllll}\text { Canadian } & \text { evidence. } & \text { Corporate } & \text { Governance, } & \text { 13(6), }\end{array}$ http://dx.doi.org/10.1111/j.1467-8683.2005.00469.x

Kyereboah-Coleman, A., \& Biekpe, N. (2006). The link between corporate governance and performance of the non-traditional export sector: Evidence from Ghana. Corporate Governance, 6(5), 609-623. http://dx.doi.org/ 10.1108/14720700610706090

Larcker, D. F., Richardson, S. A., \& Tuna, İ. (2007). Corporate governance, accounting outcomes, and organizational performance. Accounting Review, 82(4), 963-1008.

OECD. (2004). OECD principles of corporate governance. France: OECD Publications Service.

Picou, A., \& Rubach, M. J. (2006). Does good governance matter to institutional investors? Evidence from the enactment of corporate governance guidelines. Journal of Business Ethics, 65(1), 55-67. http://dx.doi.org/ 10.1007/s10551-006-0016-3 
Shleifer, A., \& Vishny, R. W. (1997). A survey of corporate governance. Journal of Finance, 52(2), 737-783.

Smith, Adam. (1937). An inquiry into the nature and causes of the wealth of nations. New York: The Modern Library.

SPK. (2005). Corporate governance principles. Ankara.

SPK. (2007). Communiqué about "the principles on rating activities and rating agencies in capital markets" published in official gazette dated 12/07/2007 and numbered 26580 Serie: VIII, Number: 51. Retrieved from http://www.spk.gov.tr/indexcont.aspx?action=showpage\&menuid=6\&pid=10\&subid=1

Standard and Poor's, GAMMA: Governance accountability, management, metrics and analysis. Retrieved from http://www2.standardandpoors.com/spf/pdf/equity/gamma_eng_2.pdf

Yen, S. (2005). Are well governed firms safe investments? Retrieved from http://ssrn.com/abstract=648401 